\title{
TRAINING PENINGKATAN KEMAMPUAN MENGANALISIS TES MENGGUNAKAN PROGRAM ANATES BAGI GURU
}

\author{
Darodjat \\ darodjatjt@gmail.com \\ Teguh Julianto \\ teguhjulianto@ump.ac.id \\ Zakiyah \\ zakiyah_ump@yahoo.com \\ Rano Subehi \\ ranosubehi@gmail.com
}

\section{UNIVERSITAS MUHAMMADIYAH PURWOKERTO}

\begin{abstract}
ABSTRAK
Kompetensi pedagogik merupakan salah satu kompetensi yang harus dimiliki oleh guru yang profesional. Salah satu indikator guru yang profesional adalah mampu melakukan kegiatan evaluasi proses dan hasil pembelajaran dengan benar. Studi pendahuluan dan Need Assessment terhadap guru di SMA Muhammadiyah 1 Purwokerto menggunakan google form secara purposive sampling menunjukan bahwa terdapat $80 \%$ guru yang belum mengenal dan menggunakan program ANATES. Berdasarkan hasil Need Assessment tersebut, maka perlu peningkatan kemampuan guru melakukan analisis butir instrumen menggunakan program ANATES. Metode yang digunakan dalam training ini yaitu metode ceramah dan praktek secara mandiri yang dilakukan di lab komputer milik SMA Muhammadiyah 1 Purwokerto. Berdasarkan responsi penilaian diri dengan menggunakan google form yang diberikan pasca pelatihan, diperoleh hasil bahwa kemampuan guru menggunakan program ANATES sebagai alat bantu untuk menganalisis kualitas butir soal meningkat $80 \%$, dan setiap peserta dapat melakukan analisis menggunakan program ANATES dengan prosedur yang benar.
\end{abstract}

Kata kunci: ANATES, Kompetensi Guru, Kemampuan Menganalisis.

\section{PENDAHULUAN}

Guru sebagai ujung tombak kesuksesan pendidikan harus memiliki persyaratan atau kompetensi sebagaimana telah diatur dalam Undang-Undang Guru dan Dosen. Salah satu di antara kompetensi yang harus dimiliki guru adalah kompetensi pedagogik. Kompetensi ini mencakup kemampuan mengelola pembelajaran peserta didik, pemahaman terhadap peserta didik, perancangan dan pelaksanaan pembelajaran, evaluasi hasil belajar, dan pengembangan peserta didik untuk mengaktualisasi berbagai macam potensi yang dimilikinya. Guru harus meningkatkan kompetensinya, bisa melalui training, seminar, pelatihan, penelitian dan kegiatan 
lainnya sehingga kualitas pembelajaran dapat terus ditingkatkan (Nugraha, 2019). Namun, hal yang menonjol dalam pengembangan kompetensi guru lebih terfokus pada pengajaran dan tugas-tugas administrasi, sementara wilayah pengembangan kompetensi profesional belum menjadi perhatian yang utama (Kurniawan \& Astuti, 2017). Jika kondisi ini tidak diatasi, maka dapat menyebabkan kemadegan dalam pengembangan guru yang profesional dan efektif yang selalu dituntut oleh masyarakat dan perubahan zaman (Arief Ardiansyah, 2018).

Salah satu tuntutan yang harus disikapi oleh para guru yang profesional adalah kemajuan ilmu pengetahuan dan teknologi. Kondisi ini memaksa para guru untuk berakselarasi dalam menggunakan IT untuk pengembangan tugas profesinya (Cahyaningrum \& Sakti, 2021). Dalam konteks pengembangan evaluasi pembelajaran, saat ini banyak dikembangkan program-program yang dapat membantu para guru melakukan analisis secara cepat, tepat dan akurat. Sebagai contoh, ada program Analisis Tes yang dikenal dengan nama ANATES yang dapat digunakan untuk menganalisis kualitas item butir, baik soal pilihan ganda maupun soal uraian (Ariany \& Al-Ghifari, 2018). Program ini penting dikuasai oleh para guru, sehingga dapat membantu mengefektifkan tugas-tugas profesinya.

Kegiatan mengevaluasi hasil belajar dipengaruhi oleh banyak faktor, salah satunya adalah faktor kualitas instrumennya. Jika instrumennya baik, maka kualitas hasil belajar juga akan baik, karena instrumennya memiliki standar yang baik, sehingga dapat mengukur apa yang seharusnya diukur. Sebaliknya, jika instrumennya tidak baik, maka kualitas hasil belajar juga tidak baik, karena bisa jadi instrumennya tidak mengukur apa yang seharusnya diukur, memiliki indeks diskriminan atau daya beda yang rendah, atau kualitas butir soalnya tidak bagus. Dengan demikian, kemampuan guru dalam menyusun instrumen tes merupakan hal yang esensial dalam pengembangan kualitas pendidikan secara luas (Prabowo et al., 2018).

Berdasarkan studi pendahuluan dan wawancara pada tanggal 22 Oktober 2020 dengan Kepala SMA Muhammadiyah 1 Purwokerto), yaitu Imam Suyanto, S. Ag. di lokasi kegiatan training Ipteks bagi Masyarakat yaitu SMA Muhammadiyah 1 Purwokerto diperoleh data bahwa selama ini para guru belum menggunakan program atau software ANATES untuk menganalisis kualitas tes. Tim IbM selanjutnya melakukan need assessment untuk kebutuhan training bagi guru di SMA tersebut.

Berikut ini adalah sajian data need asssment perlunya training bagi guru sebagai upaya peningkatan kemampuan analisis tes menggunakan program ANATES. Need assessment dilakukan menggunakan google form. Pengambilan sampel dilakukan secara purposive sampling kepada 5 guru mata pelajaran yang berdeda: pertama, ada $80 \%$ guru yang belum pernah menggunakan program ANATES, dari berbagai rumpun mata pelajaran, dan hanya $20 \%$ yang sudah mengenalnya. Namun demikian, mereka sudah menggunakan program lain yang digunakan untuk menganalisis kualitas tes.

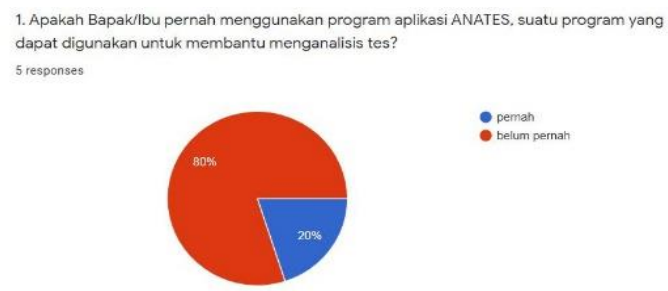

\section{Gambar 1. Pengguna ANATES}

Berdasarkan gambar 1 dan gambar 2, maka program ANATES termasuk software yang jarang digunakan, karena memang belum dikenal oleh para guru dari berbagai bidang/mata pelajaran. 


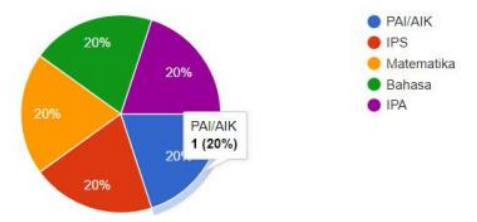

Gambar 2. Sampel Need Assessment

SMA Muhammadiyah 1 Purwokerto yang dijadikan sebagai tempat training, dan dan para guru sebagai subjek IbM memiliki banyak prestasi, salah satu di antaranya adalah telah terakreditasi A (Kebudayaan, n.d.). Namun, karena banyak yang belum akrab dengan program ANATES, maka Tim Ipteks bagi Masyarakat (IbM) melakukan kerjasama dengan pihak SMA dalam kegiatan peningkatan kemampuan guru menganalisis tes menggunakan program ANATES. ANATES merupakan salah satu program atau software yang difungsikan membantu untuk menganalisis kualitas tes secara lengkap(Ariany \& Al-Ghifari, 2018).

Training ini menjadi penting dilaksankan karena adanya kebutuhan yang diperlukan oleh para-guru di SMA tersebut. Hal ini diketahui melalui need assessment seperti yang ditunjukkan dari gambar 3 berikut.

5. Apảkāh diperlukann pelatihàn anălisis tes menggunäkân softwäre/program ANATES 5 responses

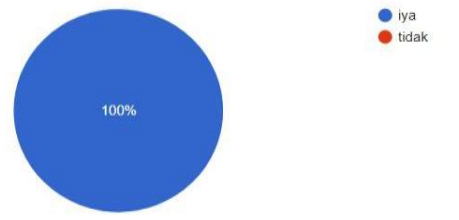

Gambar 3. Kebutuhan Training ANATES

Jadi semua sampel $(100 \%)$ memandang training ini benar-benar dibutuhkan oleh para guru. Program ANATES lebih mudah digunakan oleh para guru dan lebih menguntungkan nilainya untuk siswa (Sari \& Herawati, 2014). Untuk itu, training ini sangat tepat dilaksanakan di sekolah tersebut, dengan tujuan meningkatkan kompetensi para guru dalam menyusun soal tes dan melakukan analisis kualitas soal menggunakan program
ANATES. Manfaat training ini bagi sekolah adalah dapat meningkatkan kompetensi pedagogik guru dalam menyusun soal tes dengan kualitas yang lebih baik.

\section{METODOLOGI PELAKSANAAN}

Penentuan metode, materi dan tujuan training didasakan pada studi pendahuluan atau need assessment. Secara sederhana, alur penyusunan pelaksanaan training dapat digambarkan menjadi bagan di bawah ini.

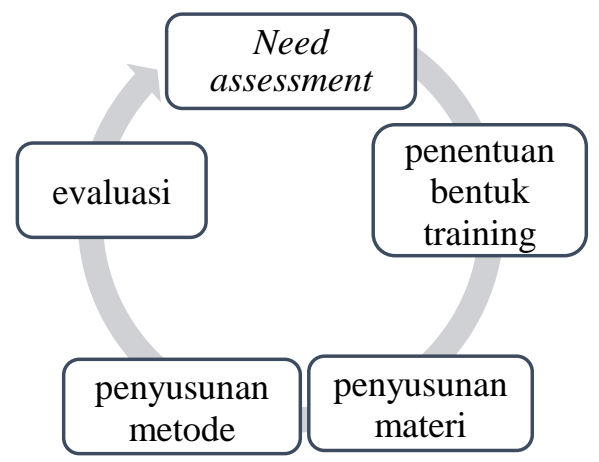

Gambar 4. Bagan Pelaksanaan Training

Adapun metode yang digunakan dalam pelaksanaan training ini ada dua macam. Pertama, metode ceramah dengan maksud agar para guru yang berasal dari berbagai rumpu keilmuan atau mata pelajaran memiliki pengetahuan dan pemahaman tentang persyaratan tes yang baik dan dapat menganalisisnya dengan cara atau metode yang cepat, tepat dan efektif jika dibandingkan dengan metode manual atau program yang sudah digunakannya, seperti Excel atau rumus manual. Para peserta mendapatkan materi secara lengkap dari input data, run data dan penafsiran output data ANATES. Dengan metode ceramah dilanjutkan dengan tanya jawab, maka pengetahuan dan wawasan para peserta di SMA tersebut dapat ditingkatkan, dan bersedia melakukan praktek secara individu program ANATES yang cukup mudah dipahami, namun hasil analisisnya melingkupi seluruh kebutuhan yang diperlukan dalam analisis tes hasil belajar yang baik.

Kedua, metode praktek atau latihan mandiri dengan menggunakan laptop atau 
komputer sendiri-sendiri, kemudian diberi materi mulai dari cara menginstal program, input data tes, run program dan analisis hasil output program. Training ini memberikan penguatan pada sisi aplikasi atau praktek bagaimana menganalisis suatu tes buatan guru dengan program tersebut.

Adapun materi yang disampaikan dalam training ini: 1) penyusunan butir soal yang baik, seperti daya bada, reliabilitas tes, tingkat kesulitan butir soal dan keberfungsian pengecoh; 2) pengenalan program analisis tes, cara menginstal program ANATES; 3) cara menjalankan program ANATES; dan 4) cara interpretasi hasil output ANATES.

Kondisi peserta training sangat aktif, namun kurang nyaman (insecure) karena adanya aturan pembatasan prosedur kesehatan akibat pandemic Covid 19, pembatasan aktivitas di sekolah, dan adanya kebijakan pembelajaran tatap muka ditiadakan, diganti dengan pembelajaran daring. Latar belakang pendidikan para peserta terdiri dari tujuh orang pria dan enam orang wanita, enam orang bidang sosial humaniora, dan tujuh orang bidang MIPA, satu orang perpendidikan S2 dan dua belas orang berpendidikan S1.

\section{HASIL DAN LUARAN}

Training peningkatan kemampuan menganalisis tes menggunakan program ANATES bagi guru di SMA Muhammadiyah 1 Purwokerto dilaksanakan 1 hari, mulai jam 08.00- 15.00 WIB. Training dibuat dalam dua termin, yaitu termin pemaparan materi untuk sesi pertama (08.30-12.00 WIB) dan sesi kedua praktek dari jam 12.30-15.00 WIB. Baik sesi pertama maupun sesi kedua dilaksanakan di laboratorium komputer milik sekolah. Karena masih dalam kondisi pandemic Covid 19, maka training ini menerapkan standar prosedur kesehatan. Materi pertama disampaikan oleh Drs. Teguh Julianto, M.Si. tentang penyusunan butir soal yang baik, meliputi daya beda soal, reliabilitas tes, tingkat kesulitan butir soal dan keberfungsian pengecoh.

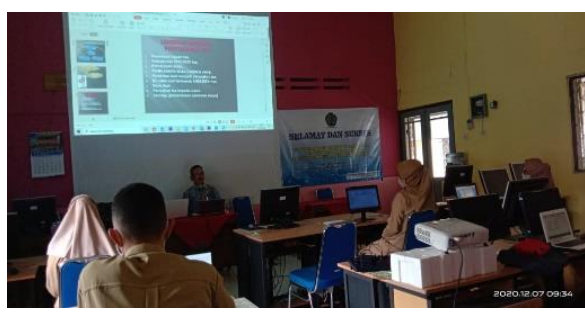

Gambar 5. Materi Penyusunan Tes oleh Drs. Teguh Julianto, M.Si.

Setelah materi pertama selesai, dilanjutkan materi kedua yaitu pengenalan program analisis tes dan cara menginstal program disampaikan, input data, run data, dan analisis output data disampaikan oleh Dr. Darodjat, M. Ag.

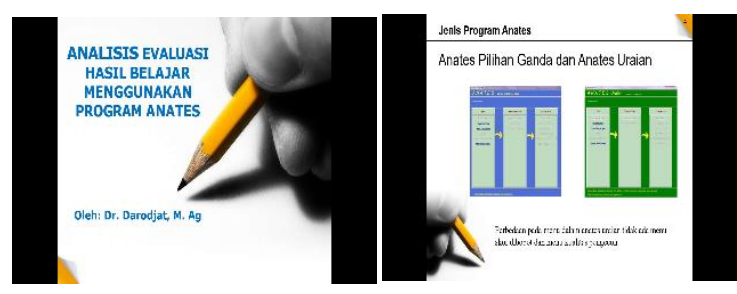

Gambar 6. Materi Program ANATES

Setelah semua materi tentang standar tes yang baik dan pengenalan program ANATES tersampaikan, maka dilanjutkan tanya jawab. Selanjutnya diteruskan ke sesi kedua yaitu praktek, mulai dari install program, memasukkan data ke dalam program, run data, dan interpretasi out put program ANATES, dan evaluasi training.

Hasil dari kegiatan training dapat dipetakan menjadi tiga bagian, yaitu hasil yang bersifat kognitif, afektif dan motorik (Darodjat \& Wahyudiana, 1993). Adapun hasil yang bersifat kognitif yaitu ada kenaikan pengetahuan baru dari sebelum mengikuti training dan setelah mengikuti training sebesar $60 \%$. Peningkatan tersebut karena para guru telah memahami teori dan praktek penyusunan butir soal yang baik, namun dalam hal pengetahuan program pengetahuan mencapai $80 \%$. Adapun hasil yang bersifat afektif, para peserta bersikap antusias mengikuti kegiatan training ini dari 
awal sampai akhir, walaupun dalam kondisi yang kurang nyaman karena terbatasi oleh prosedur kesehatan untuk menekan wabah corona 19.

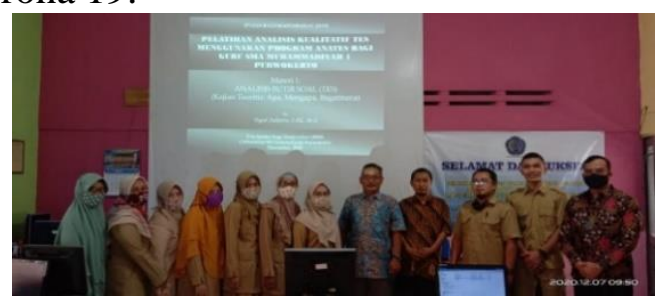

Gambar 7. Sebagian Peserta Training

Kegiatan ini mendapat sambutan hangat dan luas di kalangan guru-guru SMA Muhammadiyah 1 Purwokerto dari berbagai rumpun ilmu atau mata pelajaran yang berbeda-beda. Sesungguhnya, pihak sekolah telah menetapkan tidak ada pembelajaran dan aktifitas akademik di kelas, dan guru melaksanakan aktifitas kegiatan belajar mengajar dari rumah masing-masing, namun mereka dengan semangat mengikuti kegiatan pelatihan tersebut di ruang laboratorium IT milik sekolah. Seluruh peserta training telah mengisi angket responsi sebagai need assment dan lembar evaluasi. Bagi para guru, pelatihan ini sangat penting dan dibutuhkan oleh mereka, terutama dalam peningkatan kemampuan analisis tes menggunakan program lain yang belum gunakan.

Berdasarkan responsi penilaian diri melalui google form yang diberikan pasca pelatihan, kemampuan menggunakan program ANATES sebagai alat untuk menganalisis kualitas butir soal menjadi meningkat $80 \%$. Hal ini ditunjukkan oleh responsi peserta seperti gambar berikut.

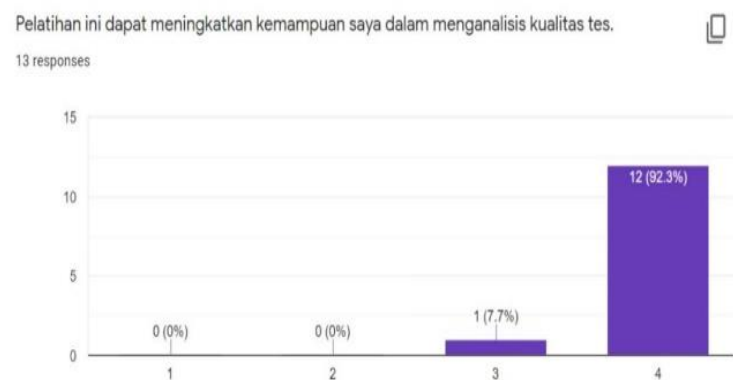

Gambar 8. Kemampuan Peserta Pasca Training
Terkait dengan kemampuan menjalankan program ANATES, para peserta pelatihan telah mampu menganalisis tes soal, mulai dari input data, run data dan menafsirkan output data dengan baik, hasilnya mencapai $90 \%$. Berikut ini adalah salah satu output data program hasil praktek yang dilakukan oleh peserta training.

\section{Tabel 1. Out put ANATES}

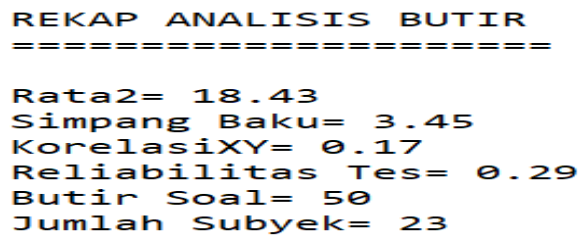

Para peserta mampu memaknai output tersebut berdasarkan teori yang telah disampaikan pada sesi pertama $100 \%$. Didapatkan koefisien reliabilitas tes pada praktek bersama sebesar 0,29, para peserta mampu memaknai bahwa data tes yang berasal dari salah satu peserta sebagai bahan analisis tergolong tes yang belum memenuhi tes yang baik, karena reliabilitasnya di bawah batas penerimaan (minimal 0,7), sementara nilai yang diperoleh 0,29 masuk kategori rendah.

Salah satu sebab tes memiliki reliabilitas yang rendah karena banyak butir soal yang tidak valid atau butir soal yang jelek. Untuk itu, butir soal yang tidak baik harus diperbaiki terlebih dahulu atau ditingkatkan kualitasnya, sehingga secara langsung akan meningkatkan besaran koefisien reliabilitasnya. Bahkan jika butir soalnya jelek, bisa jadi diperbaiki atau dibuang/dihapus, tidak diikutkan dalam daftar pertanyaan soal yang menjadi bagian dari tes.

Jadi, secara kualitatif dan kuantitatif pelatihan ini dapat dinyatakan sebagai pelatihan yang berhasil, baik dilihat dari responsi penilaian diri maupun dengan kenyataan para peserta mampu melakukan input data, run data dan analisis data menggunakan program ANATES. Beberapa faktor berikut menjadi kunci keberhasilan pelaksanaan training 
peningkatan kemampuan menganalisis tes menggunakan program ANATES bagi Guru SMA Muhammadiyah 1 Purwokerto yaitu:

1. dukungan dari kepala SMA Muhammadiyah 1 Purwokerto untuk bersinergi dan berkolaborasi dengan Tim IbM dari UMP dalam peningkatan kompetensi para guru di lingkungannya,

2. koordinasi yang baik antara Tim IbM UMP,

3. pendanaan dari UMP melalui LPPM dan fasilitasi yang baik, dan

4. antusiasme para guru dalam mengikuti pelatihan ini.

Adapun yang menjadi faktor penghambat kegiatan ini antara lain:

1. faktor kondisi pandemic Covid 19 sehingga interaksi antara Tim dan para peserta menjadi terhambat karena pemberlakuan prosedur kesehatan dan social distancing,

2. ruang dan fasilitas yang terbatas, tidak dapat digunakan karena menyesuaikan prosedur kesehatan, sehingga para peserta menjadi tidak nyaman berada dalam ruang yang panas dan kurang kondusif.
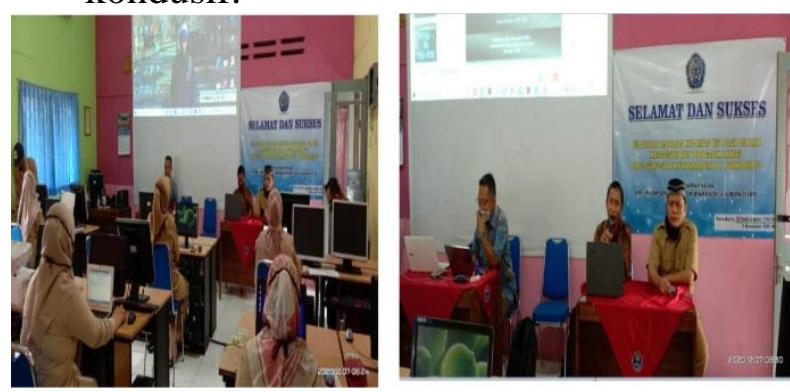

Gambar 9. Suasana Training ANATES

Target dari training atau pelatihan untuk domain kognitif adalah peningkatan pengetahuan para peserta, khususnya para guru SMA Muhammadiyah 1 Purwokerto. Secara empirik, training ini menunjukkan bahwa pengetahuan peserta meningkat, seperti ditunjukkan pada gambar berikut.

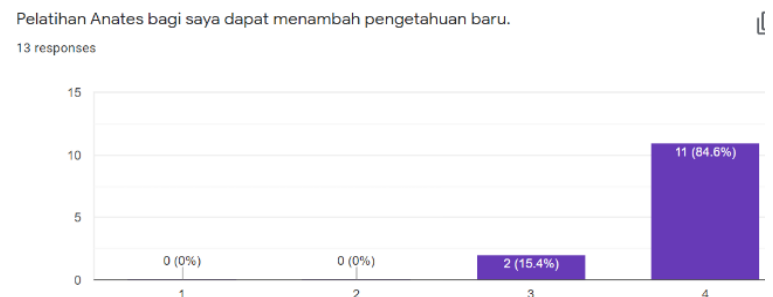

Gambar 10. Peningkatan Pengetahuan

Adapun peningkatan kemampuan peserta training, yaitu guru-guru SMA Muhammadiyah 1 Purwokerto dapat dilihat pada sajian gambar berikut ini.

Pelatihan ini dapat meningkatkan kemampuan saya dalam menganalisis kualitas tes. 13 responses

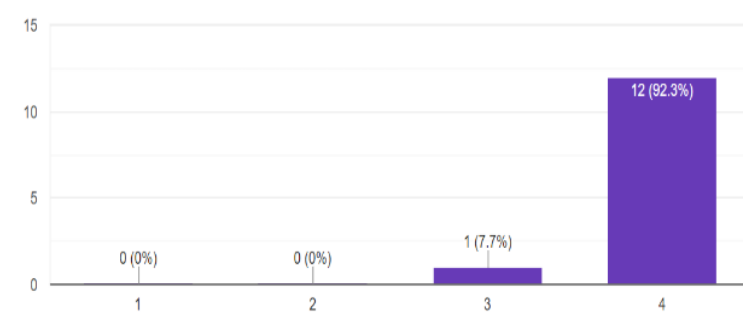

Gambar 11. Peningkatan Analisis

Berdasarkan feed back penilaian akhir terhadap kegiatan training peningkatan kemampuan menganalisis tes menggunakan ANATES untuk guru SMA Muhammadiyah 1 Purwokerto didapatkan data bawa secara kognitif atau pengetahuan dan kemampuan menjalankan program dan menafsirkan atau menganalisis hasil output ANATES meningkat $80 \%$.

\section{KESIMPULAN DAN SARAN}

Kegiatan IbM ini dilaksanakan dalam bentuk pelatihan analisis kualitas instrumen tes menggunakan program ANATES bagi Guru SMA Muhammadiyah 1 Purwokerto dapat disimpulkan sebagai berikut.

1. Pelatihan dapat berjalan dengan baik, program sesuai dengan rencana, memenuhi target dan tujuan pelatihan. Peserta yang terdiri dari 13 peserta mampu menjalankan program ANATES untuk menganalisis kualitas tes dilihat dari indeks kesulitan butir soal, 
reliabilitas tes, keberfungsian daya beda dan skor yang dicapai untuk masingmasing peserta tes (testee).

2. Berdasarkan responsi penilaian diri menggunakan google form yang diberikan pasca pelatihan, didapatkan data bahwa ada peningkatan kemampuan setelah mengikuti pelatihan program ANATES

3. Semua peserta dapat menginterpretasikan output ANATES pada reliabilitas tes, tingkat kesulitan butir soal, daya beda dan berfungsinya pengecoh.

\section{DAFTAR PUSTAKA}

Ariany, R. L., \& Al-Ghifari, A. (2018). Penggunaan Software Anates Untuk Validasi Instrumen Tes. Al-Khidmat, 1(1), 73-78. https://doi.org/10.15575/jak.v1i1.332 7.

Arief Ardiansyah. (2018). Empat Aturan Manajemen Kelas untuk Perilaku Guru Efektif di Madrasah. Vicratina Jurnal Pendidikan Islam, 3(2), 196202.

Cahyaningrum, M. N., \& Sakti, N. C. (2021). Pengembangan Media Pembelajaran Interaktif Berbasis Android dan Efek Terhadap Hasil Belajar Peserta Didik Kelas XI IPS SMA. 8(1), 21-33.

Darodjat \& Wahyudiana. (1993). Model Evaluasi Program Pendidikan. Islamadina, 1(1), 1-28.

Kebudayaan, K. P. dan. (n.d.). Data Referensi Pendidikan. http://referensi.data.kemdikbud.go.id/ index11_sd.php?kode $=052400 \& l e v e l$ $=2$

Kurniawan, A., \& Astuti, A. P. (2017). Deskripsi Kompetensi Pedagogik guru dan Calon Guru Kimia SMA Muhammadiyah 1 Semarang. Seminar Nasional Pendidikan, Sains Dan Teknologi, 1-7.

Nugraha, N. (2019). Pengaruh Motivasi Berprestasi Dan Kompetensi
Terhadap Kinerja Guru. Jurnal Pendidikan Akuntansi \& Keuangan, 2(2), https://doi.org/10.17509/jpak.v2i2.15 461

Prabowo, A., Kusdinar, U., \& Rahmawati, U. (2018). Pelatihan Pengembangan Instrumen Tes Mata Pelajaran Matematika SMP. International Journal of Community Service Learning, 2(3), 141-148. https://doi.org/10.23887/ijcsl.v2i3.14 189

Sari, A. I. C., \& Herawati, M. (2014). Aplikasi ANATES Versi 4 dalam Menganalisis Butir Soal. Faktor Jurnal Ilmiah Kependidikan, 1(2), 203-214.

https://journal.lppmunindra.ac.id/inde x.php/Faktor/article/view/353. 